\title{
A Qualitative Study of the Inclusion of Social Enterprise in the Entrepreneurial Education Curriculum
}

\author{
Michael S. Jones, Robert A. Phillips
}

Masood Enterprise Centre, Alliance Manchester Business School, University of Manchester, Manchester M15 6PB, United Kingdom.

\begin{abstract}
Despite rising interest amongst students and the general public in social enterprise, it is often taught as an add-on along with sustainability in more general entrepreneurship courses. This has led to under-equipping students with the skills and knowledge they need to start a business in this area. We spoke to both academics and students, using semi-structured interviews, about their views of current social enterprise inclusion and what could be improved. The research found that entrepreneurship academics included social issues in their courses as part of entrepreneurial education, however, this was at introductory level and students were frustrated there was little opportunity to follow up on this interest, especially those in their final year, with no clear path for those interested. Focus varied between institutions and it was suggested that the institutional focus on employability statistics could be harmful for social entrepreneurship education. We suggest that more institutions have social enterprise modules which are able to be accessed university wide to allow multidisciplinarity, and separated out from general entrepreneurship at a higher level to fully focus on these issues to fully prepare those who are interested in starting or joining a social enterprise.
\end{abstract}

Keywords: Social Enterprise; enterprise and entrepreneurship education; employability. 


\section{Introduction}

Entrepreneurship education (EE) has increased markedly in recent years, for example, a study of the evolution of EE in the US shows that in 1975 there were just 100 higher education qualifications that included entrepreneurship, increasing to 500 by 2006 (Morelix, 2015). In the majority of cases, there is a positive correlation between EE and rates of entrepreneurship (Lima et al., 2015; Fayolle and Liñan, 2014), although the extent of the impact is argued. Studies have also found that EE also increases attitudes towards entrepreneurship (Fayolle and Gailly, 2015; Heuer and Kolvereid, 2014). Bischoff et al. (2018) studied the impact of stakeholders on EE programs and found that the most common external stakeholders involved in these courses were entrepreneurs, companies and alumni. They argue that involving these stakeholders with experience in the field provided an opportunity for knowledge transfer and often led to success. Success factors range from how the course incorporates relevant cultural factors (Shi, Yao and $\mathrm{Wu}, 2019$ ) to how courses are able to create enterprising role models for students, either through discussing past examples or bringing in speakers (Fellnhofer, 2017) and feedback from alumni suggests learning by doing and courses of a practical nature work best (Phillips, 2019; Phillips, 2018).

Abu-Saifan (2012) stated that Social Entrepreneurship is the 'field in which entrepreneurs tailor their activities to be directly tied with the ultimate goal of creating social value'. There is increasing interest in creating social and cultural value, which has been recognised in the UK by the QAA, 2018. However, many universities have tried to fit SEE (Social Enterprise Education) into their existing EE curriculum without making suitable changes for the differing circumstances (Weber and Westley, 2012). Often when they are adapted, ethical frameworks and tools are rarely addressed explicitly in a course's curriculum, instead focusing more on business aspects (Steiner et al, 2018). The study found that institutions would understandably set a focus on their own field of expertise, but then neglect other content, with business schools leaning heavily on market skills but then not including political or philanthropic skills. These imbalances mean that the majority of students would finish without learning all the skills necessary to become a Social Entrepreneur. Lounsbury and Strang (2009) state that Social Entrepreneurship arises at the intersection of shifts in culture and organization structure, and therefore the best way to propel the field is to focus on a cross-disciplinary curriculum and indeed there are examples of using multi-disciplinary courses to aid this (Sanchez-Romaguera and Phillips, 2018). It is, however, noted even social enterprises need to apply business principles, with that knowledge 'residing in business schools' (Weber and Westley, 2012). Non-business schools students may have access to SEE training via extracurricular activities (e.g. Phillips, 2017 and Phillips, 2010). Recent events in the UK, including the Coronavirus pandemic and Brexit, show that uncertainty is at this point ingrained in the modern world, however, as shown earlier, academics in the field do not believe that EE is adapting to the modern world (Carolis and Litzky, 2019; Kariv et al., 
2019) and that this is having a knock-on effect onto the quality of SEE (Pache and Chowdhury, 2012; Certo and Miller, 2008). More widely, many believe that the current state of EE is not satisfactory however, suggesting students are not being sufficiently prepared for EE (Fayolle and Gailly, 2015) with Carolis and Litzky (2019) suggesting EE is too narrowly focused on the 'traditional image' of an entrepreneur, which has since evolved, and recent innovations are rarely reflected (Kariv et al., 2019). Environmental impact is an area investigated, with Greene et. al. (2018) stating that educators need to learn from wider society to provide suitably up-to-date information. It is therefore important that SEE is able to effectively prepare students for modern social and environmental issues enabling graduates to apply this knowledge to create social value. Therefore, we decided to investigate academics and students views of social enterprise with the aim of understanding where improvements could be made.

\section{Methodology}

This research was approached with a constructivist philosophy, which is widely used when discussing entrepreneurship education. We looked at the viewpoints of both students and lecturers from two different institutions - Participants were needed for two groups; academics in the field of entrepreneurship education and university-level students with an interest in social entrepreneurship, who are undertaking entrepreneurship education or have done in previous semesters and self-selected to be interviewed. The research was completed through semi-structured interviews with both students and lecturers, discussing their experience of social enterprise teaching, how it was taught, level of satisfaction and options available. The results were split into themes. 
Table 1. A summary of the subjects interviewed for this study.

\begin{tabular}{|c|c|c|}
\hline Code & Student or Academic & Details \\
\hline A1 & Lecturer, University of Manchester & Lecturer in Enterprise \\
\hline $\mathrm{A} 2$ & Lecturer, University of Manchester & Lecturer in Enterprise \\
\hline A3 & University of Southern California & $\begin{array}{l}\text { Entrepreneur and Adjunct Professor of } \\
\text { Entrepreneurship }\end{array}$ \\
\hline A4 & University of Southern California & $\begin{array}{l}\text { Entrepreneur and Adjunct Professor of } \\
\text { Entrepreneurship }\end{array}$ \\
\hline A5 & University of Birmingham & Lecturer in Entrepreneurship \\
\hline S1 & Student, University of Manchester & $\begin{array}{l}\text { BSc in Management completed } 2 \text { entrepreneurship } \\
\text { modules }\end{array}$ \\
\hline S2 & Student, University of Manchester & $\begin{array}{l}\text { BSc in International Management, completed } 2 \\
\text { entrepreneurship modules }\end{array}$ \\
\hline S3 & $\begin{array}{l}\text { Student, University of Manchester and } \\
\text { University of Southern California }\end{array}$ & $\begin{array}{l}\text { BSc International Management with American } \\
\text { Business, completed } 4 \text { entrepreneurship modules }\end{array}$ \\
\hline S4 & $\begin{array}{l}\text { Student, University of Southern California and } \\
\text { Universidad Carlos III de Madrid }\end{array}$ & $\begin{array}{l}\text { BSc International Studies and Business } \\
\text { Administration, completed } 4 \text { entrepreneurship modules }\end{array}$ \\
\hline S5 & $\begin{array}{l}\text { Student, Loughborough University, Aston } \\
\text { University }\end{array}$ & $\begin{array}{l}\text { MSc International Business, completed } 4 \\
\text { entrepreneurship modules }\end{array}$ \\
\hline
\end{tabular}

\section{Results}

a) Firstly, there was a clear interest in social enterprise by students, which was also observed by academics;

$\mathrm{S} 1$ - 'It is not possible to deny the impact that companies and their activities have in different aspects of society, not only the environment - which they mostly do - but also people's lives.' A1 - 'this interest is definitely increasing, as students are becoming fascinated by nontraditional business forms in the social space, such as social enterprises, green and sustainable enterprises, movements toward "conscious capitalism," and many others' and A3 - 'I have definitely noticed more students this year asking questions regarding issues such as climate change, especially when these topics are heavily in the public eye'

Both Academics and students agreed that in their courses, social enterprise issues are addressed, although academics accepted it was introductory level;

A2 - 'My units all do'... 'I try to introduce issues in my course around how what businesses do and what we do as individuals have an impact on what happens in society' and A4 - 'I 
think most courses try to include them somewhere, I certainly do. They're too important to the current business world to ignore wholly' with S4 - 'As I double major in International studies and business administration, some of my courses consider social movement. Nevertheless, the business side of my studies does not cover as much of said social movements'

b) However, many students found that even when they had some exposure to social issues in entrepreneurship education, there wasn't a way to expand upon this education in their current course;

S5 - 'Once I'd finished my course that included a social enterprise element, my only other choice was applying for a masters to continue (learning about social entrepreneurship), and this wasn't really a possibility for me' and S3 - 'Not at home (Manchester), no. I was able to develop some of these skills on exchange (to USC) where there were more niche options'

c) One student suggested that there were ways to develop these skills further, but required use of limited free time;

S2 - 'I have taken part in some entrepreneurial events, like the Manchester Entrepreneurs Society and start-up weekends, but I found that by third year I didn't really have time to keep going with these'.

d) Some students noted regional differences;

S3 - 'While in America (University of Southern California), courses seemed to be much more practical, real use cases and real world problems. Courses at Manchester feel much more theoretical. I definitely feel more comfortable applying my knowledge in a practical sense after my year abroad.' And S4 - 'It is true that during my year abroad, I took a business sustainability course, which was focused exclusively in the environment. I would say I lack more courses regarding social issues.' S5 also noticed a difference, but this change in institution was due to graduating with a bachelor's degree and beginning a master's degree, so a change in depth of understanding is to be expected - 'On my current course, these issues (social issues) are definitely explored much more. When it was only briefly mentioned before, I feel like now I'm learning how to apply theory to these situations'.

e) Interestingly, academics felt that goals and restrictions placed on them by their institution has limited entrepreneurship education;

A2 - 'Employability is pushed as a focus of university study, which can lead courses to be too focused on employability skills rather than developing thoughts and skills' and A5 'discussing personal interests or passions of the student group can't always be explored, time has to be generally focused on the curriculum'. Two academics raised the belief that entrepreneurship education is about more than education, but could be useful in cultural shifts 
A2 - 'I would like it to be rejected that entrepreneurship is about maximising profits, it's not, the evidence is there to show that entrepreneurs are interested in change, trying to make things better, on a deeper level, I would hope that entrepreneurs will think about what is really important' and A5 - 'I don't believe future education has to be so focused on the current climate, but preparing students for the future of entrepreneurship. This way, students can be ready to adapt to issues that arise in the world and hopefully work towards solving them'.

\section{Discussion}

Both students and academics had positive opinions of including social issues in EE courses. On specific SE topics being included in courses, there was more of a disagreement. Most students and academics felt that SE should be included within traditional EE; however, some thought that all issues aren't always relevant to every course and forcing them into every course can be disruptive. These academics suggested that either a specific SE course was added by the business school, or that the most relevant existing courses were chosen to include these issues. However, including SE in with traditional EE has given it some legitimacy. All academics interviewed stated that they had included social issues in their courses and all students had discussed social issues in at least one entrepreneurship course. There were, however, clear differences in the expectations of the breadth of this inclusion.

Where academics felt that they had successfully integrated the core ideas, most students felt that these topics were rarely explored thoroughly enough for any real proficiency in the topic, suggesting there is a difference in expectations of how social issues should be included.

Academics who believed they had elements of SE in their course admitted these were just introductory, with others using these issues as case studies to explore traditional entrepreneurship techniques. The research showed that students were hoping for a more complete look at how social issues impact upon both traditional entrepreneurship and the opportunity for SE. This difference can be possibly explained by an issue raised by the student group in the research. Students seemed to gain an interest in social topics from one module which would introduce these issues, and then have no way to follow up on these topics. This was a particular problem in final year courses, with no options to explore further in undergraduate courses and little free-time to gain experience in extra-curricular projects due to heavy final year course loads. How social issues became a part of an entrepreneurship curriculum differs between institutions, and even between faculties within an institution.

The research did find that social issues were being updated, with those discussed reflecting the global trends of the modern world. The two social issues that appeared to gain the most attention were environmentalism and sustainable living. 
A point raised by academics was how the exploration of topics such as social entrepreneurship directly clashed with the aims of their institutions. Specifically, how the university's focus on employability takes away from the other benefits of a university education, developing skills that will not just support a graduate to enter a career path. This is an issue for EE in general, as only $0.6 \%$ of students start their own business within 6 months of graduating (HESA, 2017), so for universities looking to increase employability statistics to attract future students, entrepreneurship is not necessarily an attractive focus. Since many entrepreneurs start their business later in life, it is clear that all EE cannot be judged by the same short-term metrics that universities are held to in general, but rather understood to be part of a set of skills learned either for entrepreneurship or intrapreneurship. This study was limited to a small number of participants, future work could involve exploring and comparing programmes in more detail with more participants to understand how SEE could be better integrated into a university education.

\section{References}

Abu-Saifan, S. (2012). Social Entrepreneurship: Definition and Boundaries. Technology Innovation Management Review, 2(2), 22-27.

Bischoff, K., Volkmann, C. and Audretsch, D. (2018). Stakeholder collaboration in entrepreneurship education: an analysis of the entrepreneurial ecosystems of European higher educational institutions. Journal of Technology Transfer, 43, 20-46.

Carolis, D. and Litzky, B. (2019). Unleashing the potential of university entrepreneurship education. New England Journal of Entrepreneurship, 22(1), 58-66.

Certo, S. and Miller, T. (2008). Social entrepreneurship: Key issues and concepts. Business Horizons, 51(1), 267-271.

Fayolle, A. and Liñan, F. (2014). The future of research on entrepreneurial intentions. Journal of Business Research, 67(5), 663-666.

Fayolle, A. and Gailly, B. (2015). The Impact of Entrepreneurship Education on Entrepreneurial Attitudes and Intention: Hysteresis and Persistence. Journal of Small Business Management, 53(1), 75-93.

Greene, P., Fetters, M., Bliss, R and Donnellon, A. (2018). The future of entrepreneurship education: educating for economic and social impact in ' Fayolle, A, A Research Agenda for Entrepreneurship Education, 62-80.

Fellnhofer, K. (2017). The Power of Passion in Entrepreneurship Education: Entrepreneurial Role Models Encourage Passion? Journal of Entrepreneurship Education, 20(1), 58-87.

Heuer, A. and Kolvereid, L. (2014). Education in entrepreneurship and the Theory of Planned Behaviour. European Journal of Training and Development, 38(6), 506-523.

Kautonen, T., van Gelderen, M. and Fink, M. (2015). Robustness of the Theory of Planned Behavior in Predicting Entrepreneurial Intentions and Actions, Entrepreneurship Theory and Practice, 39(3), 655-674. 
Kariv, D., Matlay, H. and Fayolle, A. (2019). Introduction: entrepreneurial trends meet entrepreneurial education in The Role and Impact of Entrepreneurship Education. Edward Elgar Publishing, 1-11.

Lima, E., Lopes, R., Nassif, V. and Silva, D. (2015). Opportunities to Improve Entrepreneurship Education: Contributions Considering Brazilian Challenges. Journal of Small Business Management, 53(4), 1033-1051.

Lounsbury, M. and Strang, D. (2009). Social Entrepreneurship: Success Stories and Logic Construction In Hammack, D and Heydemann, S, Globalization, Philanthropy, and Civil Society. Indianapolis, Indiana University Press.

Morelix, A. (2015). The evolution of entrepreneurship on college campuses, Ewing Marion Kauffman Foundation. Available at: https://www.kauffman.org/currents/the-evolutionof-entrepreneurship-on-college-campuses/ (Accessed: 8 March 2020).

Pache, A. and Chowdhury, I. (2012). Social Entrepreneurs as Institutionally Embedded Entrepreneurs: Toward a New Model of Social Entrepreneurship Education. Academy of Management Learning \& Education, 11(3), 494-510.

Phillips, R. A. (2018). A Retrospective Study on the Views of Alumni Entrepreneurs Towards University Enterprise Education and Training. IUP Journal of Knowledge Management, 16(3), 54-71.

Phillips, R. A. (2010). Encouraging a more enterprising researcher: the implementation of an integrated training programme of enterprise for $\mathrm{Ph}$. D. and postdoctoral researchers. Research in Post - Compulsory Education, 15(3), 289-299.

Phillips, R.A. (2019). Using Alumni Entrepreneurs Feedback to shape University Entrepreneurship Education. 5th International Conference on Higher Education Advances (HEAd'19) 85-93.

Phillips, R.A. (2017). Measuring Entrepreneurial outcomes from a residential enterprise school for postgraduate researchers. Journal of Asia Entrepreneurship and Sustainability, 13(2), 62-89.

Sanchez-Romaguera, V. and Phillips, R.A. (2018). A comparison of a first and third year UG enterprise unit: lessons from experiential learning and interdisciplinarity. 4th International Conference on Higher Education Advances (HEAd'18), 899-907.

Shi, L., Yao, X. and Wu, W. (2019). Perceived university support, entrepreneurial selfefficacy, heterogeneous entrepreneurial intentions in entrepreneurship education. .Journal of Entrepreneurship in Emerging Economies.

QAA (2018). Enterprise and Entrepreneurship Education: Guidance for UK Higher Education Providers, Available at: https://www.qaa.ac.uk/docs/qaas/enhancement-anddevelopment/enterprise-and-entrpreneurship-education-2018.pdf?sfvrsn=15f1 f981_8 (Accessed: 23 March 2020).

Weber, M. and Westley, F. (2012). Social Innovation and Social Enterprise in the Classroom: Frances Westley on Bringing Clarity and Rigor to Program Design. Academy of Management Learning \& Education, 11(3), 409-418.

Worsham, E. and Dees, G. (2012). Reflections and Insights on Teaching Social Entrepreneurship: An Interview with Greg Dees. Academy of Management Learning \& Education, 11(3), 442-452. 